\title{
HARGA, PROMOSI, DAN KUALITAS PELAYANAN SEBAGAI ANTESEDEN KEPUASAN PELANGGAN YANG DI MEDIASAI OLEH KEPUTUSAN MENGGUNAKAN OJEK ONLINE DI YOGYAKARTA
}

\author{
Taufiq Hidayat \\ taufik.th896@gmail.com \\ Universitas Ahmad Dahlan \\ Sukardi \\ sukardi_feuad@yahoo.com \\ Universitas Ahmad Dahlan
}

\begin{abstract}
ABSTRAK
Customer satisfaction is an asset for the company to be a benchmark for the company's success in serving customers. Since its establishment in 2010, GOJEK has consistently served the community, presenting efficient and effective transportation to the Indonesian people spread across several cities. By maintaining the values of a friendly Indonesian character. The population in this study were GO-JEK users. While the sample in this study is GO-JEK users more than once in the city of Yogyakarta. The sampling technique uses a nonprobability sampling method. While the data used in this study are primary data by obtaining the data needed by using information techniques, namely by distributing questionnaires. The analysis tool uses multiple linear regression, and doing a partial test knowing whether the independent variables individually have a significant effect on the dependent variable, do the r-test to measure the ability of the model to explain the ability of the dependent variable.

The results of the analysis can be concluded that: Price does not have a positive effect on user decisions. Promotion does not have a positive effect on user decisions. Service quality does not have a positive effect on user decisions. User decisions have a positive effect on customer satisfaction. User decisions do not mediate between Price, Promotion and Quality of Service.
\end{abstract}

Keywords: price, promotion, service quality, user decision, customer satisfaction.

\begin{tabular}{l}
\hline \multicolumn{3}{c}{ PENDAHULUAN } \\
$\begin{array}{c}\text { GO-JEK } \\
\text { merupakan }\end{array}$ \\
$\begin{array}{l}\text { perusahaan } \\
\text { transportasi } \\
\text { menggunakan teknologi berjiwa }\end{array}$ \\
yang bosial \\
kesejahteraan pekerja di berbagai sektor \\
informal di Indonesia. Kegiatan GO-JEK \\
bertumpu pada 3 nilai pokok: kecepatan, \\
inovasi, dan dampak sosial. Di era yang \\
modern seperti sekarang ini, transportasi \\
menjadi salah satu penunjang penting \\
dalam kegiatan sehari -hari terutama di \\
daerah perkotaan. Transportasi yang baik \\
dapat mencerminkan keteraturan kota
\end{tabular}

yang baik pula, hal ini disebabkan karena transportasi merupakan suatu alat bantu dalam mengarahkan pembangunan di daerah perkotaan. Selain itu, transportasi juga merupakan suatu prasarana bagi pergerakan manusia atau barang yang timbul akibat adanya kegiatan di daerah perkotaan. Transportasi merupakan sarana perkembangan yang penting dan strategis dalam memperlancar roda perekonomian, memperkukuh persatuan dan kesatuan serta mempengaruhi semua aspek kehidupan. Transportasi dapat membantu perekonomian yang baik disuatu daerah bahkan disuatu negara. Semakin baik dan tertatanya transportasi disuatu daerah akan 
semakin baik pula perekonomiannya. Dengan adanya pertumbuhan penduduk yang semakin meningkat mempengaruhi kebutuhan akan jasa transportasi yang semakin meningkat pula, hal inilah yang menyebabkan semakin berkembangnya dunia bisnis di sektor jasa transportasi. Yogyakarta merupakan kota pelajar dan juga kota wisata yang terkenal di dunia lokal maupun international, maka semakin banyak juga jumlah kendaraan dan alat transportasi yang membuat Jogja semakin padat dan macet. Dalam hal ini juga jasa transportasi yang di sediakan oleh pemerintah belum di gunakan secara sepenuhnya oleh masyarakat Jogja maupun pendatang yang ada di wilayah Yogyakarta, saat ini masyarakat atau mahasiswa lebih memilih menggukan kendaraan pribadi di bandingkan dengan menggunakan jasa transportasi yang di sediakan oleh pemerintah dengan alasan yang beragam. Ini juga merupakan sebuah permasalahan yang saat ini harus di perhatikan oleh pemerintah daerah maupun provinsi untuk memperbaiki system dan jalur yang di lewati oleh masyarakat, sehingga sangat mudah untuk mengakses tujuannya.

Belum lama ini muncul sebuah terobosan baru dalam hal perusahaan transportasi umum, yang menggunakan teknologi sehingga bisa dipesan melalui smartphone/telpon genggam kita. Ojek online ini sangat berbeda sistem pada ojekojek biasa yang sudah ada dari dahulu yaitu kita harus mencarinya di jalan secara manual terlebih dahulu dan membayar dengan tarif yang disepakati antara tukang ojek dan penumpangnya. Tapi dalam sistem ojek online ialah masyarakat hanya tinggal menginstall aplikasi yang sudah disediakan oleh perusahaan ojek online lalu dengan memilih menu yang tersedia kita sudah dapat melihat ojek online yang ada di sekitar tempat kita berada, jadi dapat langsung diposisikan dengan yang terdekat, sehingga dapat cepat menjemput kita. Lalu kita tinggal memasukkan alamat tujuan dan seketika muncul tarif yang harus dibayar oleh pengguna berdasarkan jarak kilometer, bukan hanya untuk sarana transportasi saja ojek online ini juga dapat kita gunakan untuk keperluan membeli makanan/ mengambil barang-barang kita di suatu tempat. Dinamika persaingan bisnis jasa pada saat ini mengharuskan setiap perusahaan yang bergerak dibidang ini untuk senantiasa melakukan berbagai strategi agar dapat merebut hati konsumen. Perusahaan harus dapat menerapkan strategi yang tepat dalam menarik minat konsumen untuk melakukan penggunaan kembali jasa yang ditawarkan. Kunci untuk mempertahankan pelanggan adalah dengan memberikan kepuasan pelanggan yang pada akhirnya akan menciptakan loyalitas pelanggan. Menurut Kotler (2016) kepuasan konsumen adalah merupakan perasaan senang atau kecewa seseorang yang muncul setelah membandingkan antara kinerja (atau hasil) yang di harapkannya. Saat ini beberapa peneliti pemasaran berfokus pada pengukuran kepuasan pelanggan. Hal ini terbukti dengan adanya peningkatan kualitas pelayanan dari perusahaan untuk meningkatkan kepuasan pelanggan akan memberikan perhatian bagi manajer perusahaan apakah perlu dilakukan perbaikan dalam kepuasan pelanggan yang berperan pada peningkatan dalam kinerja ekonomis perusahaan.

Transportasi antar jemput yang sebelumnya manual sekarang menerapkan system teknologi dan di kordinir oleh prusaan menamakan diri GO-JEK. GOJEK merupakan salah satu penyedia layanan jasa transportasi online khususnya sepeda motor. GO-JEK adalah perusahaan berjiwa 
sosial yang memimpin revolusi industri transportasi ojek. GO-JEK bermitra dengan para pengendara ojek berpengalaman di Jakarta meliputi area JABODETABEK, Bandung, Bali dan Surabaya. GO-JEK menjadi solusiutama dalam pengiriman barang, pesan antar makanan, berbelanja dan berpergian di tengah kemacetan. Aplikasi GO-JEK dapat diunduh pada smartphone yang memiliki sistem operasi iOS dan Android. GO-JEK memenfaatkan media elektronik, dengan itu akses untuk pemesanan jasa ojek lebih mudah bagi konsumen ojek khususnya di kota Jogja. Dengan menggunakan aplikasi di smartphone kemudian gojek akan menjemput konsumennya dan mengantar pelanggan sampai pada tempat tujuannya.

Harga adalah merupakan sesuatu yang diserahkan dalam pertukaranuntuk mendapatkan suatu barang atau jasa (Lamb, 2001). Faktor harga sangat mempengaruhi terhadap keputusan penggunaan jasa, GOJEK sebagai perusahaan jasa menawarkan harga yang relatif terjangkau dibandingkan dengan perusahaan jasa yang lain, adanya potongan harga yang diberikan, sehingga membuat konsumen tertarik untuk menggunakan jasa mereka.

Tidak hanya untuk antar-jemput, GO-JEK pun menyediakan berbagai layanan lain seperti GO-FOOD yang dapat menjemput makanan favorit anda dari mana saja sesuai pesanan anda, kemudian ada GO-MART salah satu layanan GO-JEK y ang siap sedia untuk membelanjakan kebutuhan anda seharihari dan masih banyak lagi fitur-fitur yang diberikan oleh GO-JEK Indonesia. Walaupun GO-JEK sudah tidak asing lagi dikalangan masyarakat khususnya di Jogjakarta, namun jasa di bidang transportasi ini harus tetap memperhatikan kenyamanan, keamanan serta kepuasan konsumennya. Jika konsumen puas akan pelayanan yang diberikan oleh GO-JEK maka pelanggan GO-JEK akan menggunakan jasa GO-JEK secara berulang (repeat buying) yang kemudian bisa menjadi pelanggan yang setia (loyal customer) sehingga perusahaan GO-JEK Indonesia sangat berpeluang menjadi market leader dan hal ini akan menjadikan perusahaan semakin maju dan dipercaya oleh pelanggan di Indonesia. Sebagai sebuah perusahaan jasa tentunya GO-JEK juga telah berupaya menerapkan strategi harga, promosi dan kualitas pelayanan yang tepat guna menarik konsumen untuk menggunakan kembali jasa GO-JEK.

Faktor lain yang mendukung kepuasan pelangan adalah promosi. Promosi merupakan salah satu kegiatan pemasaran yang penting bagiperusahaan dalam upaya mempertahankan kontinuitas serta meningkatkaan kualitas penjualan untuk meningkatkan kegiatan pemasaran dalam hal memasarkan barang atau jasa dari suatu perusahaan. Pada umumnya perusahaan jasa melakukan promosi agar para konsumen tertarik untuk memakai dan menggunakan kembali jasa tersebut. GO-JEK telah mendisain promosi seperti dengan memasang iklan, memberikan potongan harga jika menggunakan GOPAY dengan target utama adalah para konsumen yang sudah menggunakan jasa di perusahaan jasa tesebut.

Tujuan dari penelitian ini adalah: 1) untuk menganalisis apakah terdapat pengaruh positif harga terhadap keputusan pembelian ojek online GO-JEK (studi kasus pada pengguna di kota Yogjakarta), 2) untuk menganalisis apakah terdapat pengaruh positif promosi terhadap keputusan pembelian ojek online GO-JEK (studi kasus pada pengguna di kota Yogjakarta), 3) untuk menganalisis apakah terdapat pengaruh positif kualitas 
pelayanan terhadap keputusan pembelian ojek online GO-JEK (studi kasus pada pengguna di kota Yogjakarta) dan 4) untuk menganalisis apakah terdapat pengaruh positif harga, promosi, kualitas layanan, dan keputusan pembelian terhadap kepuasan pelanggan ojek online GO-JEK (studi kasus pada pengguna di kota Yogyakarta).

\section{REVIEW LITERATUR DAN HIPOTESIS}

\section{Landasan Teori}

1. Harga

Kotler (2008) mengemukakan bahwa harga merupakan satu-satunya elemen bauran pemasaran yang menghasilkan pendapatan, elemenelemen lainnya menimbulkan biaya.

2. Promosi

Menurut Kotler (2014) promosi adalah pemasaran sebagai proses dimana perusahaan menciptakan nilai bagi pelanggan dan membangun pelanggan yang kuat relationship untuk menangkap nilai dari pelanggan sebagai imbalan.

3. Kualitas Pelayanan

Tjiptono (2012) kualitas dapat diartikan sebagai kondisi dinamis yang berhubungan dengan produk, jasa, sumber daya manusia, proses, dan lingkungan yang memenuhi atau melebihi harapan.

4. Keputusan Pembelian

Keputusan pembelian menurut Kotler (2012) adalah keputusan pembeli tentang pilihan merek yang akan dibeli, tetapi dua faktor bisa berada antara niat pembelian dan keputusan pembelian. Faktor pertama adalah sikap orang lain.

5. Kepuasan Pelanggan

Menurut Kotler (2013) kepuasan konsumen adalah tingkat perasaan seseorang setelah membandingkan (kinerja atau hasil) yang dirasakan dibandingkan dengan harapannya.

\section{Penelitian Terdahulu}

Marati (2016) melakukan penelitian dengan judul pengaruh kualitas pelayanan dan harga terhadap kepuasan pelanggan jasa transportasi ojek online Gojek di Surabaya. Hasilnya kualitas pelayanan dan harga mempunyai pengaruh yang positif dan signifikan secara parsial terhadap kepuasan pelanggan jasa transportasi ojek online Gojek di Surabaya.

Astri (2016) melakukan penelitian dengan judul analisis kepuasan konsumen GOJEK di wilayah kota Bandung. Hasilnya kualitas layanan GOJEK sangat berpengaruh terhadap kepuasan konsumen dan price pun memiliki pengaruh yang signifikan terhadap kepuasan.

\section{Hipotesis}

H1: Variabel harga berpengaruh positif terhadap kepuasan pelayanan ojek online GO-JEK (studi kasus pada masyarakat di kota Yogyakarta).

$\mathrm{H} 2$ : Variabel promosi berpengaruh posistif terhadap kepuasan pelayanan ojek online GO-JEK (studi kasus pada masyarakat di kota Yogyakarta).

H3: Variabel kualitas layanan berpengaruh positif terhadap kepuasan pelayanan ojek online GOJEK (studi kasus pada masyarakat di Yogyakarta).

H4: Variabel harga, promosi, dan kualitas pelayanan berpengaruh positif terhadap keputusan pembelian dan kepuasan pelanggan terhadap ojek online GO-JEK (studi kasus pada masyarakat di kota Yogyakarta) 


\section{METODE PENELITIAN}

\section{Populasi dan Sampel}

Populasi adalah wilayah generalisasi yang terdiri atas objek/subjek yang mempunyai kualitas dan karakteristik tertentu yang ditetapkan oleh peneliti untuk mempelajari kemudian ditarik kesimpulan Sugiyono (2016). Populasi dalam penelitian ini adalah masyarakat di kota Yogyakarta y ang menggunakan jasa GOJEK.

Sampel adalah bagian dari jumlah dan karakteristik yang dimiliki oleh populasi tersebut Sugiyono (2016). Sedangkan sampel dalam penelitian ini yaitu sebagian dari jumlah pengguna ojek online di Yogyakarta.

\section{Definisi Operasional}

1. Variabel Dependen

$$
\text { Kepuasan Pelanggan (Y) }
$$

merupakan perasaan senang atau kecewa seseorang yang muncul setelah membandingkan kinerja (hasil) produk yang dipikirkan terhadap kinerja (hasil) yang diharapkan GOJEK.

\section{Variabel Independen}

Harga (X1) yaitu seberapa besar nilai yang dikeluarkan mahasiswa untuk menggunakan jasa GOJEK. Promosi (X2) yaitu satu komunikasi yang digunkan GOJEK untuk memberikan informasi yang bertujuan untuk merubah sikap dan perilaku konsumen, yang tadinya tidak mengenal menjadi mengenal sehingga menggunakan jasa GOJEK. Kualitas Pelayanan (X3) yaitu tingkat keunggulan yang diharapkan GOJEK dan pengendalian atas tingkat keunggulan tersebut untuk memenuhi keinginan pelanggan.

\section{Variabel Mediasi}

Keputusan pembelian (Z) yaitu suatu tindakan konsumen untuk membentuk refrensi di antara merekmerek dalam kelompok pilihan dan membeli produk yang di sukai.

\section{Uji Instrumen}

1. Uji Validitas

Sugiyono (2012) menyatakan bahwa instrumen yang valid berarti alat ukur yang digunakan untuk mendapatkan data (mengukur) itu valid. Valid berarti instrumen tersebut dapat digunakan untuk mengukur apa yang seharusnya diukur. Kuesioner dikatakan valid jika jika pertanyaan pada kuesioner mampu mengungkapkan sesuatu yang diukur oleh kuesioner tersebut. Alat uji validitas dalam penelitian ini adalah Confirmatory Factor Analisis (CFA) dengan nilai faktor loading lebih besar dari 0,5 dikatakan valid, untuk memudahkan dalam melakukan uji validitas, maka digunakan analisis faktor yang ada pada program komputer SPSS.

2. Uji Reliabilitas

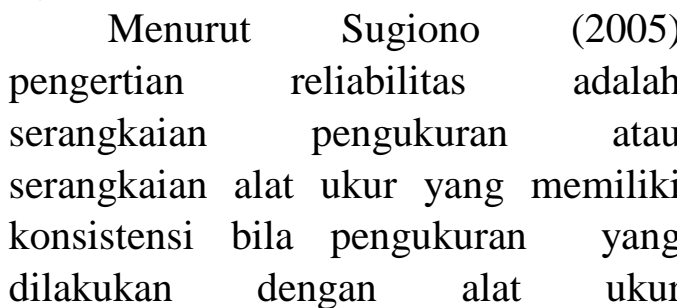
realibilitas tersebut dilakukan secara berulang. Kriteria dikatakan reliabel atau dapat dipercaya ditentukan dengan nilai $\alpha$ (cronbanch alpha) lebih besar sama dengan nilai batas yang ditentukan atau standarisasi sebesar 0,6. Standarisasi merupakan batas yang digunakan untuk mengukur tingkat konsistensi suatu variabel independent mempengaruhi variabel dependen. Ghozali (2009) menyatakan 
bahwa reliabilitas adalah alat untuk mengukur suatu kuesioner yang merupakan indikator dari peubah atau konstruk. Suatu kuesioner dikatakan reliabel atau handal jika jawaban seseorang terhadap pernyataan adalah konsisten atau stabil dari waktu ke waktu. Reliabilitas suatu test merujuk pada derajat stabilitas, konsistensi, daya prediksi, dan akurasi. Pengukuran yang memiliki reliabilitas yang tinggi adalah pengukuran yang dapat menghasilkan data yang reliabel.

\section{Teknik Analisis Data}

1. Analisis Regresi Berganda Regresi Linear Berganda digunakan oleh peneliti. Bila peneliti bermaksud meramalkan bagaimana keadaaan (naik-turunya) variabel dependen bila dua atau lebih independen sebagai variabel independen (Sugiyono, 2008), sehingga penelitian ini dapat dirumuskan dengan: $\mathrm{Y} 1=\mathrm{a}+\mathrm{b} 1 \mathrm{X} 1+\mathrm{b} 2 \mathrm{X} 2+\mathrm{b} 3 \mathrm{X} 3$

Keterangan:

$\mathrm{Y}=($ Variabel dependen $)$

$\mathrm{a}=$ Konstanta

$\mathrm{b}=$ Koefisien

$\mathrm{X}=$ Variabel Independen

\section{Uji Hipotesis}

\section{Uji Parsial (Uji T)}

Uji $\mathrm{t}$ digunakan untuk menguji secara parsial masing-masing variabel. Hasil uji $t$ dapat dilihat pada tabel coefficients pada kolom sig (significance). Jika probabilitas nilai $\mathrm{t}$ atau signifikansi $<0,05$, maka dapat dikatakan bahwa terdapat pengaruh antara variabel bebas terhadap variabel terikat secara parsial. Namun, jika probabilitas nilai $\mathrm{t}$ atau signifikansi > 0,05, maka dapat dikatakan bahwa tidak terdapat pengaruh yang signifikan antara masing-masing variabel bebas terhadap variabel terikat.

\section{Uji Koefisien Determinasi}

Uji ini bertujuan untuk menentukan proporsi atau persentase total variasi dalam variabel terikat yang diterangkan oleh variabel bebas. Apabila analisis yang digunakan adalah regresi sederhana, maka yang digunakan adalah nilai $\mathrm{R}$ Square. Namun, apabila analisis yang digunakan adalah regresi berganda, maka yang digunakan adalah Adjusted R Square. Hasil perhitungan Adjusted R2 dapat dilihat pada output Model Summary. Pada kolom Adjusted R2 dapat diketahui berapa persentase yang dapat dijelaskan oleh variabelvariabel bebas terhadap variabel terikat, sedangkan sisanya dipengaruhi atau dijelaskan oleh variabel-variabel lain yang tidak dimasukkan dalam model penelitian. 


\section{HASIL PENELITIAN DAN PEMBAHASAN}

\section{Hasil Analisis Responden}

\begin{tabular}{|c|c|c|c|c|}
\hline NO. & & Keterangan & Frekuensi & Persentase \\
\hline 1 & Jenis Kelamin & 1. Perempuan & 44 & 62,9 \\
\hline & & 2. Laki-laki & 26 & 37,1 \\
\hline & Total & & 70 & 100 \\
\hline 2 & Usia & 1. $17-24$ tahun & 55 & 80,0 \\
\hline & & 2. 24 - 32 tahun & 10 & 15,7 \\
\hline & & 3. Diatas 32 tahun & 5 & 4,3 \\
\hline & Total & & 70 & 100 \\
\hline 3 & Pendapatan & 1. $0-\mathrm{Rp} 1.000 .000$ & 16 & 22,9 \\
\hline & & 2. Rp $1.000 .000-R p$ & 38 & 54,3 \\
\hline & & 2.500 .000 & & \\
\hline & & 3. Diatas Rp 2.500 .000 & 16 & 22,9 \\
\hline & Total & & 70 & 100 \\
\hline 4 & Pekerjaan & 1. Pegawai Negeri Sipil & 2 & 2,9 \\
\hline & & 2. Wiraswasta & 11 & 15,7 \\
\hline & & 3. Mahasiswa/pelajar & 57 & 81,4 \\
\hline & Total & & 70 & 100 \\
\hline 5 & Menggunakan & 1. 2 kali & 16 & 22,9 \\
\hline & jasa GO-JEK & 2. Lebih 2 kali & 54 & 77,1 \\
\hline & Total & & 70 & 100 \\
\hline
\end{tabular}

Berdasarkan tabel di atas yang menunjukan responden dalam penelitian ini adalah responden dengan jenis kelamin dari 70 responden terdiri dari perempuan sebanyak 44 orang atau $62,9 \%$ dan lakilaki 36 orang atau $37,1 \%$. Hal ini karena, sebagian penyebaran kuesioner lebih banyak pada perempuan.

Responden dalam penelitian ini dengan berusia 17-24 tahun sebanyak 56 orang atau $80,0 \%$, yang berusia 24-32 tahun sebanyak 11 atau $15,7 \%$, berusia diatas 32 tahun dengan sebanyak 3 orang atau 4,3\%. Hal ini, karena sebagian pelanggan merupakan mahasiswa yang dominan menggunakan jasa transportasi ojek online GO-JEK.

Pendapatan atau uang saku dari responden yaitu antara lain 0 Rp1.000.000 sebanyak 57 orang atau
$81,4 \%$, Rp 1.000.000 - Rp 2.500 .000 dengan sebanyak 38 orang atau 54,3\%, kemudian diatas $\mathrm{Rp} 2.500 .000$ sebanyak 16 orang. Hal ini, karena sebagian responden yaitu mahasiswa dan rata-rata masih diberikan uang saku.

$$
\text { Pekerjaan responden yang }
$$
dijadikan sampel terdiri dari pegawai negeri sipil sebanyak 2 orang atau 2,9\%, wiraswasta 11 orang atau $15,7 \%$, mahasiswa sebanyak 57 orang atau $81,4 \%$. Responden sebagian besar mahasiswa sehingga yang belum berpendapatan. Jumlah menggunakan jasa ojek online di Yogyakarta yaitu, 2 kali menggukann ada 16 orang atau 22,9\%, lebih dari 2 kali ada sebanyak 54 orang atau $54 \%$.

\section{Hasil Penelitian}

1. Hasil Uji Validitas

\begin{tabular}{|c|c|c|c|c|c|c|}
\hline \multicolumn{7}{|c|}{ Hasil Uji Validitas } \\
\hline \multirow[t]{2}{*}{ Variabel } & Pertanyaan & \multicolumn{5}{|c|}{ Komponen } \\
\hline & & & 2 & 3 & 4 & 5 \\
\hline Harga & $\begin{array}{l}1.1 \\
1.2 \\
1.3 \\
1.4\end{array}$ & $\begin{array}{l}0,614 \\
0,771 \\
0,643 \\
0,623\end{array}$ & & & & \\
\hline Promosi & $\begin{array}{l}2.1 \\
2.2 \\
2.4\end{array}$ & & $\begin{array}{l}0,837 \\
0,845 \\
0,773\end{array}$ & & & \\
\hline $\begin{array}{l}\text { Kualitas } \\
\text { pelayanan }\end{array}$ & $\begin{array}{l}3.1 \\
3.2 \\
3.3 \\
3.4 \\
\end{array}$ & & & $\begin{array}{l}0,764 \\
0,856 \\
0,525 \\
0,701\end{array}$ & & \\
\hline $\begin{array}{l}\text { Keputusan } \\
\text { pembelian }\end{array}$ & $\begin{array}{l}4.1 \\
4.2 \\
4.3 \\
4.4 \\
4.5\end{array}$ & & & & $\begin{array}{l}0,67 . \\
0,79 \\
0,84 \\
0,80 \\
0,72 .\end{array}$ & \\
\hline $\begin{array}{l}\text { Kepuasan } \\
\text { pelanggan }\end{array}$ & $\begin{array}{l}5.1 \\
5.2 \\
5.3 \\
5.4 \\
5.5\end{array}$ & & & & & $\begin{array}{l}0,701 \\
0,894 \\
0,704 \\
0,718 \\
0,504\end{array}$ \\
\hline
\end{tabular}


Berdasarkan tabel di atas, dapat diketahui semua butir pertanyaan dari 5 (lima) variabel yang dinyatakan valid dan tidak ada butir pertanyaan yang dibuang, karena nilai CFA sudah lebih besar 0,5. Menurut Ghozali (2013) kriteria atau syarat suatu item tersebut dinyatakan valid adalah diatas 0,5 dan tingkat signifikansi penelitian adalah berada dibawah 0,05 .

2. Hasil Uji Reliabilitas

Hasil Uji Reliabilitas pada Seluruh Variabel Penelitian

\begin{tabular}{|c|c|c|c|}
\hline$N_{0}$ & Variabel & $\begin{array}{c}\text { Croncbanch's } \\
\text { Alpha }\end{array}$ & Keterangan \\
\hline 1 & Harga $\left(X_{1}\right)$ & 0,626 & Reliabel \\
\hline 2 & Promosi $\left(X_{2}\right)$ & 0,674 & Reliabel \\
\hline 3 & Kualitas pelayanan $\left(X_{3}\right)$ & 0,675 & Reliabel \\
\hline
\end{tabular}

\begin{tabular}{|c|c|c|c|}
\hline 4 & Keputusan pembelian (Z) & 0,824 & Reliabel \\
\hline 5 & Kepuasan pelanggan $(Y)$ & 0,746 & Reliabel \\
\hline
\end{tabular}

Dari tabel di atas maka hasil dari uji reliabilitas dapat dijelaskan sesuai dengan nilai Croncbanch's Alpha variabel. Berikut penjelasannya :

Harga pada keputusan pembelian, nilai yang dihasilkan oleh variabel ini sebesar 0,626 dimana sesuai ketentuan nilai 0,626 lebih besar dari 0,60 sehingga hasil dari variabel tanggap dalam pengujian yaitu tidak reliabel. Dalam variabel ini setiap butir pernyataan dan jawaban konsisten.

Promosi pada keputusan pembelian, nilai yang dihasilkan oleh variabel ini sebesar 0,674 dimana sesuai ketentuan nilai 0,674 lebih besar dari 0,60 sehingga hasil dari variabel tanggap dalam pengujian yaitu reliabel. Dalam variabel ini setiap butir pernyataan dan jawaban konsisten.

Kualitas layanan pada keputusan pembelian, nilai yang dihasilkan oleh variabel ini sebesar 0,675 dimana sesuai ketentuan nilai 0,675 lebih besar dari 0,60 sehingga hasil dari variabel tanggap dalam pengujian yaitu reliabel. Dalam variabel ini setiap butir pernyataan dan jawaban konsisten.

Keputusan pembelian, nilai yang dihasilkan oleh variabel ini sebesar 0,824 dimana sesuai ketentuan nilai 0,824 lebih besar dari 0,60 sehingga hasil dari variabel tanggap dalam pengujian yaitu reliabel. Dalam variabel ini setiap butir pernyataan dan jawaban konsisten.

Kepuasan pelanggan, nilai yang dihasilkan oleh variabel ini sebesar 0,746 dimana sesuai ketentuan nilai 0,746 lebih besar dari 0,60 sehingga hasil dari variabel tanggap dalam pengujian yaitu reliabel. Dalam variabel ini setiap butir pernyataan dan jawaban konsisten.

Berdasarkan analisis yang telah dilakukan dapat disimpulkan bahwa dari seluruh pertanyaan yang ada telah memenuhi ketentuan dengan memiliki nilai Croncbanch's Alpha lebih besar dari 0,60 yang menjadikan hasil dari variabel harga, promosi, kepuasan layananan dinyatakan reliabel. Variabel dependen dalam penelitian inipun memiliki nilai Croncbanch's Alpha 0,755 lebih besar dari 0,60. Sehingga dari variabelvariabel yang dinyatakan reliabel memiliki kekonsistensian antara pernyataan dan jawaban yang diberikan responden. 
3. Hasil Uji Regresi Linier Berganda

Model 1

Hasil Uji Hipotesis pada Seluruh Variabel Penelitian

\begin{tabular}{|c|c|}
\hline \multirow{2}{*}{ Model } & $\begin{array}{c}\text { Unstandarized } \\
\text { Coefisient }\end{array}$ \\
\cline { 2 - 2 } & $\mathrm{B}$ \\
\hline 1 (Constant) & 2,389 \\
\hline $\mathrm{X}_{1}$ & 0,032 \\
\hline $\mathrm{X}_{2}$ & 0,265 \\
\hline $\mathrm{X}_{3}$ & 0,026 \\
\hline
\end{tabular}

Berdasarkan hasil tersebut dapat diperoleh persamaan regresi sebagai berikut :

$\mathrm{Y}=\mathrm{a}+\mathrm{B} 1 \mathrm{X} 1+\mathrm{B} 2 \mathrm{X} 2+\mathrm{B} 3 \mathrm{Z} 3$

$\mathrm{Y}=2,389+0,032 \mathrm{X} 1+0,265 \mathrm{X} 2+$ $0,026 \mathrm{Z3}$

Setiap nilai dari persamaan regresi diatas dapat diinterpretasikan yaitu :

a: 2,389 merupakan nilai constant.

Jika nilai dari $\mathrm{X} 1, \quad \mathrm{X} 2$, dan X3dimisalkan 0 maka nilai dari keputusan pembelian akan menurun sebesar 2,389.

b1: 0,032 koefisien bernilai positif artinya terjadi hubungan positif antara harga (X1) dengan keputusan pembelian (Z). Jika nilai kualitas produk (X1) semakin besar maka nilai keputusan pembelian (Z) akan besar. Koefisien harga (X1) sebesar 0,032 artinya jika nilai variabel independen lainnya tetap dan jika variabel harga (X1) mengalami kenaikan 1 satuan maka keputusan pembelian (Z) naik sebesar 0,032 .

b2: 0,265 koefisien bernilai positif artinya terjadi hubungan positif antara promosi (X2) dengan keputusan pembelian (Z). Jika nilai promosi (X2) semakin besar maka nilai keputusan pembelian $(\mathrm{Z})$ akan besar. Koefisien promosi (X2) sebesar 0,265 artinya jika nilai variabel independen lainnya tetap dan jika variabel promosi (X2) mengalami kenaikan 1 satuan maka keputusan pembelian (Z) naik sebesar 0,265.

b3: 0,026 koefisien bernilai positif artinya terjadi hubungan antara kualitas layanan (X3) dengan keputusan pembelian (Z). Jika nilai kualiatas (X3) semakin besar maka nilai keputusan pembelian (Z) akan besar. Koefisien kualitas layanan (X3) sebesar 0,026 artinya jika nilai variabel independen lainnya tetap dan jika variabel kualitas layanan (X3) mengalami kenaikan 1 satuan maka keputusan pembelian (Z) naik sebesar 0,026.

Model 2

Hasil Uji Hipotesis pada Seluruh Variabel Penelitian

\begin{tabular}{|c|c|}
\hline \multirow{2}{*}{ Model } & $\begin{array}{c}\text { Unstandarized } \\
\text { Coefisient }\end{array}$ \\
\cline { 2 - 2 } & $\mathrm{B}$ \\
\hline 1 (Constant) & 1,211 \\
\hline $\mathrm{X}_{4}$ & 0,304 \\
\hline
\end{tabular}

Berdasarkan hasil tersebut dapat diperoleh persamaan regresi sebagai berikut :

$\mathrm{Z}=\mathrm{a}+\mathrm{B} 1 \mathrm{Y} 1$

$\mathrm{Z}=1,211+0,304 \mathrm{Y} 1$

Setiap nilai dari persamaan regresi diatas dapat diinterpretasikan yaitu :

a: 1,211 merupakan nilai constant. Jika nilai dari $\mathrm{Z}$ dimisalkan 0 maka nilai dari loyalitas nasabah akan menurun sebesar 1,211.

b1: 0,304 koefisien bernilai positif artinya terjadi hubungan positif antara keputusan pembelian (Z) dengan kepuasan pelanggan (Y). Jika nilai keputusan pembelian (Z) semakin besar maka nilai kepuasan pelanggan (Y) akan besar. Koefisien keputusan pembelian (Y) sebesar 0,304 artinya jika nilai variabel 
dependen lainnya tetap dan jika variabel keputusan pembelian ( $\mathrm{Z}$ ) mengalami kenaikan 1 satuan maka kepuasan pelanggan (Y) naik sebesar 0,304 .

\section{Uji Mediasi}

a. Pengaruh Kualitas Harga Terhadap Kepuasan Pelanggan Dengan Dimediasi Keputusan Pembelian.

Pengujian dilakukan dengan tahapan langkah sebagai berikut:

Pengaruh langsung

X1 terhadap Y : 0,068

Pengaruh tidak langsung

$\mathrm{X} 1 \mathrm{ke} \mathrm{Z}$ ke Y : $0,212 * 0,253=0,053$



Dapat disimpulkan dari hasil pengujian lebih mendasarkan pada ketentuan dimana pengaruh langsung lebih besar dibandingkan pengaruh tidak langsung, maka dinyatakan bahwa keputusan pembelian bukan sebagai variabel mediasi.

Keputusan pembelian dalam model penelitian ini tidak memediasi hubungan antara harga terhadap kepuasan pelanggan jasa ojek online GO-JEK di Yogyakarta. Harga berpengaruh positif dan signifikan secara langsung terhadap kepuasan pelanggan melalui keputusan pembelian. Meskipun nilai pengaruh tidak langsung lebih kecil dibandingkan dengan nilai pengaruh langsungnya.

b. Pengaruh Promosi Terhadap Kepuasan Pelanggan Dengan Dimediasi Keputusan Pembelian.
Pengujian dilakukan dengan tahapan langkah sebagai berikut: Pengaruh langsung

X2 terhadap Y : 0,142

Pengaruh tidak langsung

$\mathrm{X} 2$ ke $\mathrm{Z}$ ke $\mathrm{Y}: 0,237 * 0,235=0,055$

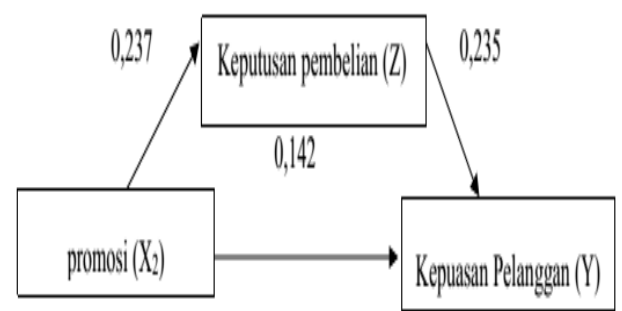

Dapat disimpulkan dari hasil pengujian lebih mendasarkan pada ketentuan dimana pengaruh langsung lebih besar dibandingkan pengaruh tidak langsung, maka dinyatakan bahwa keputusan pembelian bukan sebagai variabel mediasi.

Keputusan pembelian dalam model penelitian ini tidak memediasi hubungan antara promosi terhadap kepuasan pelanggan jasa ojek online GO-JEK di Yogyakarta. Promosi berpengaruh positif dan signifikan secara langsung terhadap kepuasan pelanggan melalui keputusan pembelian. Meskipun nilai pengaruh tidak langsung lebih kecil dibandingkan dengan nilai pengaruh langsungnya.

c. Pengaruh Kualitas Pelayanan Terhadap Kepuasan Pelanggan Dengan Dimediasi Keputusan Pembelian.

Pengujian dilakukan dengan tahapan langkah sebagai berikut:

Pengaruh langsung

X3 terhadap Y : 0,204

Pengaruh tidak langsung

X3 ke Z ke Y : $0,014 * 0,252=0,003$ 


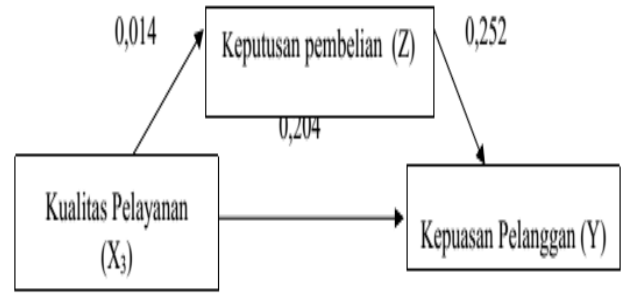

Sehingga dapat disimpulkan dari hasil pengujian lebih mendasarkan pada ketentuan dimana pengaruh langsung lebih besar dibandingkan pengaruh tidak langsung, maka dinyatakan bahwa keputusan pembelian bukan sebagai variabel mediasi.

Keputusan pembelian dalam model penelitian ini tidak memediasi hubungan antara kualitas pelayanan terhadap kepuasan pelanggan jasa ojek online GO-JEK di Yogyakarta. Kualitas pelayanan berpengaruh positif dan signifikan secara langsung terhadap kepuasan pelanggan melalui keputusan pembelian. Meskipun nilai pengaruh tidak langsung lebih kecil dibandingkan dengan nilai pengaruh langsungnya.

\section{Hasil Uji Parsial (Uji T)}

\section{Model 1}

Hasil Uji Signifikansi Parsial (Uji T)

\begin{tabular}{|c|c|}
\hline \multirow{2}{*}{ Variabel } & Hasil Uji \\
\cline { 2 - 2 } & Sig. \\
\hline Harga & 0,769 \\
\hline Promosi & 0,132 \\
\hline Kualitas layanan & 0,906 \\
\hline
\end{tabular}

Berdasarkan nilai signifikansi yang dihasilkan uji secara parsial dapat dijelaskan sebagai berikut:

a. Variabel Harga mempunyai nilai signifikan $0,769>0,05$. Maka dapat disimpulkan bahwa secara individual variabel harga tidak berpengaruh secara signifikan terhadap variabel keputusan pembelian.

b. Variabel Promosi mempunyai nilai signifikan $0,132>0,05$. Maka dapat disimpulkan bahwa secara individual variabel promosi tidak berpengaruh secara signifikan terhadap variabel keputusan pembelian.

c. Variabel Kepuasan Pelayanan mempunyai nilai signifikan $0,906>$ 0,05 . Maka dapat disimpulkan bahwa secara individual variabel Kualitas Pelayanan tidak berpengaruh secara signifikan terhadap variabel keputusan pembelian.

Model 2

Hasil Uji Signifikansi Parsial (Uji T)

\begin{tabular}{|c|c|}
\hline \multirow{2}{*}{ Variabel } & Hasil Uji \\
\cline { 2 - 2 } & Sig. \\
\hline Keputusan pembelian & 0,001 \\
& \\
\hline
\end{tabular}

Variabel keputusan pembelian mempunyai nilai signifikan $0,001<$ 0,05. Maka dapat disimpulkan bahwa secara individual variabel Keputusan Pembelian berpengaruh secara signifikan terhadap variabel kepuasan pelanggan.

6. Hasil Uji Koefisien Determinasi

Model 1

Hasil perhitungan koefisien determinasi

\begin{tabular}{|c|c|}
\hline Model & RSquare \\
\hline 1 & 0,058 \\
\hline Berdasaran & $-\cdot$ analisis yang
\end{tabular}
dilakukan, model I nilai $\mathrm{R}$ Square, diketahui nilai koefisien determinasi (R Square) sebesar 0,058. Besarnya angka koefisien determinasi ( $\mathrm{R}$ Square) 0,058 sama dengan 5,8\%. Angka 
tersebut mengandung arti bahwa variabel independen (X1 ; Harga, X2 : Promosi, X3 : Kualitas layanan) berpengaruh terhadap variabel dependen ( $\mathrm{Z}$ : Keputusan pembelian) sebesar 5,8\%. Sedangkan sisanya $(100 \%-5,8 \%=94,2 \%)$ dipengaruhi oleh variabel lain diluar model regresi ini.

Model 2

Hasil perhitungan koefisien determinasi

\begin{tabular}{|c|c|}
\hline Model & R Square \\
\hline II & 0,065 \\
\hline
\end{tabular}

Dari output hasil analisis model II uji $\mathrm{R}$ Square, diketahui nilai koefisien determinasi ( $\mathrm{R}$ Square) sebesar 0,065. Besarnya angka koefisien determinasi ( $\mathrm{R}$ Square) 0,065 sama dengan 6,5\%. Angka tersebut mengandung arti bahwa variabel independen $(Z$; keputusan pembelian) berpengaruh terhadap variabel dependen (Y: kepuasan pelanggan) sebesar $6,5 \%$. Sedangkan sisanya $\quad(100 \%-6,5 \%=35 \%)$ dipengaruhi oleh variabel lain diluar model regresi ini.

\section{Pembahasan}

1. Pengaruh Harga Terhadap Keputusan Pembelian.

Dari uji hipotesis yang dilakukan bahwa harga tidak mempunyai pengaruh yang positif terhadap keputusan pembelian dalam menggunakan jasa transportasi ojek online GO-JEK di Yogyakarta. Hal ini menunjukkan bahwa harga tidak menentukan sebuah keputusan pemgguna terhadap jasa transportasi ojek online GO-JEK di Yogyakarta. Hal ini terjadi karena harga yang di tawarkan ketika jumlah awal yang di tawarkan oleh aplikasi GO-JEK berubah ketika ada terjadi kemacetan, sehinnga ini menunjukkan bahwa harga yang dibayarkan pengguna pasca menggunakan jasa ojek online tidak sesuai oleh GO-JEK di Yogyakarta. Oleh sebab itu harga tidak berpengaruh positif terhadap keputusan pembelian.

2. Pengaruh Promosi Terhadap Keputusan Pembelian.

Dari uji hipotesis yang dilakukan bahwa promosi tidak mempunyai pengaruh yang positif terhadap keputusan pembelian pada jasa transpotasi ojek online di Yogyakarta. Ini menunjukkan bahwa promosi tidak menentukan sebuah keputusan pembelian terhadap jasa transpotasi online GO-JEK di Yogyakarta. Hal ini terjadi di sebabkan promosi yang di lakukan oleh GO-JEK tidak sesuai dengan apa yang terjadi di lapangan terkait informasi penting soal harga yang beruba, dari pihak GO-JEK pun tidak di jelaskan secara jelas sebab dan faktor terjadi perubahan pada saat macet sehingga permintaan berkurang, karena ini sangat penting di ketahui oleh pengguna jasa ojek online. Oleh sebab itu maka promosi tidak berpengaruh positif terhadap keputusan pengguna ojek online

3. Pengaruh Kualitas Pelayanan Terhadap Keputusan Pembelian.

Dari hasil analisis diketahui bahwa kualitas layanan tidak berpengaruh positif pada keputusan pembelian dalam menggunakan jasa ojek online GO-JEK di Yogyakarta. Ini menunjukkan bahwa kualitas pelayanan tidak menentukan sebuah keputusan pembelian terhadap jasa transportasi ojek online GO-JEK di Yogyakarta. Dalam hal ini di sebabkan oleh perusahaan yang tidak menghukum driver ojek online yang 
sering melanggar rambu-rambu lalu lintas dan sering kali para harga yang sudah di tetapkan berubah dalam keadaan tertentu, sehingga ini menyebabkan bahwa kulaitas layanan yang diberikan oleh GO-JEK tidak berpengarus positif terhadap keputusan pengguna ojek online.'

4. Pengaruh Keputusan Pembelian Terhadap Kepuasan Pelanggan.

Dari uji hipotesis yang dilakukan bahwa keputusan pembelian mempunyai pengaruh yang positif terhadap kepuasan pelayanan. Dalam menggunakan jasa ojek online GO-JEK Yogyakarta. Hal ini pengguna terhadap jasa ojek online GO-JEK Yogyakarta. Hal ini menunjukkan bahwa hasil yang diterima pengguna ojek online pasca menggunakan layanan yang dilakukan oleh GO-JEK di Yogyakarta berpengaruh terhadap kepuasan pelanggan. Pada saat terjadi adanya gangguan aplikasi GO-JEK maka konsumen berharap adanya perbaikan setelah terjadi gangguan pada aplikasi GO-JEK. Kompensasi yang diterima pelanggan membuat pelanggan merasa senang sehingga akan timbul adanya kepuasan pelanggan itu sendiri.

5. Pengaruh Harga, Promosi, Kualitas Layanan Sebagai Kepuasan Pelanggan Yang Dimediasi Oleh Keputusan Pembelian.

Dari hasil uji mediasi yang di lakukan bahwa harga, promosi, kualitas layanan sebagai kepuasan pelanggan yang dimediasi oleh keputusan pembelian tidak berpengaruh. Dilihat dari standardized coefisients dari harga, promsi, kualitas layanan terhadap kuputusan pembelian dan harga, promosi, kualitas layanan terhadap kepuasan pelanggan menunjukkan bahwa pengaruh langsung lebih besar di bandingkan pengaruh tidak langsung, maka dinyatakan bahwa keputusan pembelian bukan sebagai variabel mediasi terhadap harga, promosi kualitas layanan ke kepuasan pelanggaan.

\section{KESIMPULAN DAN SARAN}

\section{Kesimpulan}

1. Harga tidak berpengaruh positif terhadap keputusan pembelian.

2. Promosi tidak berpengaruh positif terhadap keputusan pembelian.

3. Kualitas layanan tidak berpengaruh positif terhadap keputusan pembelian.

4. Keputusan pembelian tidak memediasi Harga, promosi, dan kualitas layanan terhadap kepuasan pelanggan.

5. Keputusan pembelian berpengaruh positif terhadap kepuasan pelanggan.

\section{Saran}

1. Dengan banyaknya jumlah responden yang menjawab setuju terhadap seluruh variabe; penelitian (harga, promosi, kualitas pelayanan, keputusan pembelian, dan kepuasan pelanggan). Dengan adanya hal tersebut diharapkan GO-JEK dapat lebih mempertahankan harga yang memuaskan secara konsisten.

2. Nilai R Square (R2) pada model I diketahui sebesar 0,058. Besarnya angka koefisien determinasi (R Square) 0,058 sama dengan 58\%. Angka tersebut mengandung arti bahwa variabel independen mampu memberikan pengaruh terhadap variabel dependen sebesar 58\%. Sedangkan sisanya $(100 \%-58 \%=$ $52 \%$ ) dipengaruhi oleh variabel lain diluar model regresi ini.

3. Nilai R Square (R2) pada model II sebesar sebesar 0,065. Besarnya 
angka koefisien determinasi ( $\mathrm{R}$ Square) 0,065 sama dengan 65\%. Angka tersebut mengandung arti bahwa variabel independen mampu memberikan pengaruh terhadap variabel dependen sebesar $65 \%$. Sedangkan sisanya $(100 \%-65 \%=$ $35 \%$ ) dipengaruhi oleh variabel lain diluar model regresi ini.

\section{DAFTAR PUSTAKA}

Astri, Fuji RS, dkk. (2016). Analisis Kepuasan Konsumen GOJEK Di Wilayah Kota Bandung. Politeknik Negeri Bandung.

Ghozali, Imam. (2009). Aplikasi Analisis Multivariate dengan program SPSS. Semarang: UNDIP.

Ghozali, Imam. (2013). Aplikasi Analisis Multivariate dengan program SPSS. Semarang: UNDIP.

Kotler, Philip dan Gary Armstrong. (2008). Prinsip-Prinsip Pemasaran. Erlangga. Jakarta

Kotler, Philip dan Kevin Lane Keller, (2012). Manajemen Pemasaran. Jakarta: Penerbit Erlangga

Kotler, Philip and Gary Armstrong. (2014). Principle of Marketing. Pearson: New Jersey.

Kotler, Philip and Kevin Lane Keller. (2016). Marketing Management (16th Edition). New Jersey: Prentice Hall Published.

Lamb, Charles W., Hair, Joseph F., dan Mc Daniel. (2001). Pemasaran Buku. Jakarta:Salemba Empat

Marati, Nafisa Choirul dan Tri Sudarwanto. (2016). Pengaruh Kualitas Layanan Dan Harga Terhadap Kepuasan Pelanggan Jasa Transportasi Ojek Online (Studi Pada Konsumen GOJEK Di Surabaya). Universitas Negeri Surabaya.
Sugiyono. (2005). Metode Penelitian Bisnis. Bandung: Alfabeta.

Sugiyono. (2008). Metode Penelitian Kuantitatif Kualitatif dan $R \& D$. Bandung: Alfabeta.

Sugiyono. (2012). Metode Penelitian Kuantitatif Kualitatif dan $R \& D$. Bandung: Alfabeta.

Sugiyono. (2016). Metode penelitian kuantitatif, kualitatif dan $R \& D$. Bandung: PT Alfabeta.

Tjiptono, Fandy dan Gregenius Chandra. (2012). Pemasaran Strategik. Yogyakarta: ANDI. 